[O'Neill, A-M. (1993). Education Policy Initiatives for Girls and Women: Are We Included in the Decent Society? New Zealand Annual Review of Education, 2, 35-69]

\section{Education Policy Initiatives for Girls and Women: Are We Included in the Decent Society?}

\section{ANNE-MARIE O'NEILL}

As an Auckland graffiti expressed it: "The hidden hand of the market is white and hairy." But more than that, the market model hides what that white and hairy hand is doing to the rest of us. The effects on women of policy changes are obscured by the new right language in which they are couched. They appear to promise us what we were asking for, but turn out to undermine what we already have (Hill, 1992, p. 39)

$\mathrm{F}$ our years ago when I began as an Assistant Lecturer teaching a paper called Women and Education at Massey University, the concerns of an emerging "sociology of women's education in Aotearoa" (Arnot, 1980; Middleton, 1988) seemed more immediate and clearer than they do now. ${ }^{1}$ Now, as we realise the full magnitude of Labour's betrayal which National has exacerbated in their quest for the "decent society", the project for the sociology of women's education seems more urgent, confused and contradictory than ever. Many of the earlier struggles have been overcome, while many continue. Now there is a need to understand and challenge current educational policy initiatives and their implications for girls and women, within the context of the massive challenges to the hegemony of social democratic liberalism. These challenges have meant that the disjunctions between theory, policy and practices have widened rather than contracted.

The retraction of the state from its rather "inconvenient sense of social responsibility" (Bunkle and Lynch, 1992, p. 26) has meant the forging of a new educational settlement (Grace, 1990, p. 170). ${ }^{2}$ Underpinning this is a particular conception of the individual, the reconceptualising of education from that of a public good to a
36 Anne-Marie O’Neill

commodity to be bought and sold like any other on the market, and the belief that state provision has been a destructive rather than a constructive process in our history. This ideological position and the reality of the structural change it has accompanied, has been legitimised by the sometimes elaborate and sometimes scant references to "equity": the equality of outcomes or results. Thus far the fiscal imperatives underlying educational change have dominated this settlement (see Lauder and Wylie, 1990 and Middleton et al., 1990). Against the primacy of an androcentric ${ }^{3}$ market model, "equity" concerns, particularly educational outcomes for women and girls, appear to be of no consequence to the current administration. Educational policy and practices must always be understood in relation to the wider social relations of which they are an integral part. Therefore the recent educational restructuring and current policies must be seen against the backdrop of an administration which has consistently attacked the personal, structural and political gains that women have made. In its first term, with a level of $10.3 \%$ unemployment, ${ }^{4}$ the National Government has repealed the Employment Equity Act, cut welfare benefits and implemented six month stand-downs, cut funding for post-compulsory education for mature students, implemented market rentals for state owned housing, implemented user-pays in the health sector, dismantled labour market protection mechanisms, particularly important for its feminised sectors, and indulged in massive spending sprees to promote its own legislation (see Boston and Dalziel (1992) for detailed discussions of these changes). This championing of a market-driven, conservative neo-libertarianism has meant that more than ever before in our contemporary history, large groups of people, particularly women and children, have been abandoned by the state, and confined to lives of misery, fear and desperation (see The Report of the Peoples' Select Committee (1992) for the realities of this).

An understanding of contemporary policy contexts comes from knowing something of those of the past. In these times of "market, choice, efficiency and output" mania, it is tempting to look back in nostalgic recollection to those of a more pluralist consensus-driven educational policy formation. The implications and outcomes of educational policy making for girls and women seemed so much clearer then. Or did they?

The first part of this chapter will discuss the implications of a Keynesian social democratic, consensus based policy context, and the 
understanding of gender relations embodied in such policies. These will be contrasted with the assumptions underlying educational policy during the partial transition of the New Zealand state along neolibertarian principles. This will be done in order to tease out the conceptions of gender relations implicit in both the strands of liberal theory underpinning these positions. This discussion will inform the last section on current policy initiatives for girls and women in education.

\section{Liberalism}

Liberal philosophies and ideologies have provided the basis upon which the social and economic systems of western societies have been built, reproduced and understood. Historically, such assumptions within education have been perceived as given, and as unproblematic and remained clear of critical enquiry. Liberal percepts embody specific conceptions of the human essence, the social world, democratic government, the role of the state and the degree to which a central collectivity should intrude upon our lives. Its philosophical origins should not be understood as a static set of ahistorical rationales. Liberalism is a socially and historically variable set of discourses, the interpretation of which has been altered and reshaped, but certainly not disfigured out of recognition, to reflect its modernity. Such discourses have been integral to the development of individual subjectivity and the ideological construction of reality. It is through these (and other competing, dominant and non-dominant discourses) that people are positioned (e.g., as male, lesbian, Maori), to shape the conscious patterning of their lives as thinking and reflecting initiators of acts in a structured world (Theoborn, 1980, p. 15). In our society liberal discourses have become a constitutive part of the ideological hegemony which upholds the power structures and divisions underlying capitalist social relations.

\section{The Liberal Individual}

In classical liberal theory, individuals were conceptualised neither as "moral wholes" nor as part of a larger social whole, but as the private owners of their own "essence" and accordingly their own social and economic fortunes. This relation of ownership was paramount to an individual's freedom and the realisation of innate potential. It became the core of the understanding of the nature of every person. It is important to remember that the main features of what Sharpe (1980, p. 108) terms the "bourgeois subject" emerged out of the rise of the male property owning classes in the seventeenth and eighteenth centuries. The contemporary understanding of the liberal individual appears as universal, as a non-gendered form. However classical liberal philosophers were decidedly androcentric (and ethnocentric) in their equation of rationality with humanity. Thus liberal conceptions of "individual freedom" and "equality", while popularly implying a neutral universalism, were, along with the notions of "worker", "social" and "political", gendered conceptions. They were constructed on the basis of the naturalness and legitimacy of male attributes, capacities and modes of activity which, reflective of the power relations of the times, constituted "rationality". As Middleton maintains:

Together with savages (non-Europeans), the indigent (unpropertied classes), and the insane, women were perceived as irrational creatures of passion, who could therefore justifiably be denied the rights of citizenship (such as the rights to own property or to vote). (1990, p. 69)

The divergence in various strands of liberal intellectual and philosophic thought is illustrated through the partial political abandonment of social democratic liberalism around the world. The ascendency of the fourth Labour Government in 1984 and a conglomeration of certain other political and social factors, ushered in the challenge of a revived neoclassical liberalism. This functioned as an ideological counterpart to pressures to partially change the nature of the regime of accumulation, from that of Keynesianism ${ }^{6}$ to monetarism. ${ }^{7}$ A re-emphasis on the possessive qualities of the privatised individual against the backdrop of a market mechanism has important implications for how women are conceptualised and how gender relations and sexual politics are understood $^{8}$.

\section{Social-Democratic Liberalism}

New Zealand has always had an interventionist state. The early welfare measures of the Liberals laid the basis for its sustained permeation into the realms of civil society. In 1935 the first Labour Government looked to the basic principles of Keynesian state welfarism to rectify the ravages of the uneven distribution of surplus value, and the inequalities between capital and labour which became so apparent in the Depression. 
Consistent with global trends, state intervention into, and regulation of the economy, came to be seen as the answer to the expansive problems which purely market mechanisms had failed to solve. A regulatory state would ensure favourable conditions for profitable capital accumulation while assuming collective responsibility for public welfare through the provision of health, education, housing, income maintenance and other services. This implied a revised conception of the classical liberal notion of the individual. Under Keynesianism, the citizenship rights ${ }^{9}$ embodied in its policy prescriptions ensured the right to personal safety, health and welfare, regardless of social position (see Lauder, 1990, pp. 33-38 and Apple, 1990, pp. 5-19 for extended discussions of this).

One of the main features of Keynesian social democracy was the "historical compromise" between capital and labour. Workers abandoned calls for socialist reconstruction and demands for structural change, and accepted government policies and the bargaining and welfare mechanisms the state set up for them. Most, if not all, twentieth century bourgeois economic and social thought reflected this central compromise, which extended the power of the state through its intervention into civil society to every aspect of people's lives. The success of this compromise was contingent upon acceptance of a wider set of compromises existing between:

... natural rights, individualism and utilitarianism, property rights and human rights, liberalism and welfarism, capital and labour - a compromise which became increasingly embedded in economic policy. (O'Connor, 1984, p. 201)

The main political compromise between capital and labour shifted the central issue underlying class conflict from struggles over control of the mode of production to those to do with the volume of its distribution and growth. It was premised upon the assumption that the interests of both workers and capital need to be served in order to maintain stable political and economic conditions so that production and profitable accumulation could take place. More interestingly, as $\mathrm{O}^{\prime}$ Connor points out, it embodied a whole host of other compromises, the conflicts and contradictions of which, underlie all policy initiatives, and permeate all aspects of our social relations, under democratic capitalism.

Feminist theorists have teased out these contradictions somewhat more imaginatively in order to uncover their mediation in women's lives. In Cox and James' (1987) analysis of New Zealand under capitalism, they proceed upon the basis that the concept of a divided world is embedded deep in our understanding and the organisation of our lives. Initially highlighted in anthropological work, the two pivotal dualisms of the public and private realms can be traced from their origins in Western European thought, through to their permeation of all forms of modern liberalism. The problems inherent in the generalisation of these divisions through rigid analytical models to the understanding of all women's lives, are now well documented (Helly and Reverby, 1992). However, for the purposes of this discussion this pervasive metaphor (through the power of its legitimating ideologies) is useful for understanding some of the contradictions embodied in the policy initiatives and organisation of liberal states, be they welfarist or neolibertarian.

The dualism of the public and private shelters others under its rubric. These include the subjective and material dichotomies of society/family, work/domesticity, production/reproduction, outer/inner and impersonal/personal (Cox and James, 1987, p. 2). It is on the basis of the central dualism that a sexually divisive moral code lies deep in our psyches and has been openly endorsed in Keynesian policy or hidden by its legitimating ideologies. This has meant that the meaning and reality of citizenship under democratic welfarism is full of contradictions and paradoxes. The two realms are taken to be:

... twin monoliths, not to be questioned and not to be changed. They are used to justify the sexual division of labour: ${ }^{10}$ men work in the outside world and get paid for what they do, whereas women are housewives who don't get paid. This assumption is still powerful, but it is no longer unquestioned. Women's participation in paid work is increasingly recognised. But there is still an odd form of double-think when it comes to accepting the presence of women in the outside world. (ibid, p. 3)

Keynesianism sought to promote "active" economic policies with the fundamental intent of expanding productivity, production and profits. This "politicised" and inherently gendered version of the economy and the social world was an insurance not primarily for workers but very definitely for capital (O'Connor, 1973, p. 138). ${ }^{11}$

Hence the necessity to un pack and critically examine the ideological rationales which permeated Keynesian policies and the realities of their implementation. Throughout this century the pervasive view of the state in social democratic collectivist thought saw it as benign. It was 
understood to be a "bystander" or a "referee" presiding over existing rules, or an interventionist promoting "fairness" for all. Essentially the state was thought to be a neutral mechanism through which political decisions could be fairly arrived at, for the good of all. Keynesian political interpretations of liberal theory meant the enactment of social policies premised upon the belief in equal opportunities for all, implying the same for all. However we know that such policies predominantly empowered men, and certain groups of women because of the contradictions they were based upon. ${ }^{12}$ It is also important to realise that some policies had the potential, and did, enable women to usurp the dominant social order or to escape dependency relationships. ${ }^{13}$ The welfare state has, historically, reinforced women's identity as men's (breadwinner-workers) dependents both directly and indirectly (Burton, 1985; Pateman, 1989; James and Saville-Smith, 1989). Ideologies of equality embodied biologically essentialist rationales, which conceptualised the place of women in social relations in relation to their biology, their capacity for childbearing. Implicit in such rationales is the belief that women will naturally engage in unpaid domesticlabour, they will be a subservient sexual, intellectual and emotional partner in heterosexual marriage thus upholding the patriarchal conception of the traditional nuclear family. The development of the welfare state presupposed that certain aspects of welfare would and should be provided by women in the home and not through the public realm. Frequently this kind of policy rhetoric held out the promise of equal opportunities (access and options) for women in the public realm. Often tempered with references to future homemaking and child rearing, it was assumed that if women wanted to have a career, however unusual or unnatural this might be, it was simply up to them to get one. It would always be contingent, however, upon their mediation of the private realm. Naturalistic assumptions about human nature and sexuality also rest deep in our psyches and underlie the workings of many institutions and social processes, e.g., the education system, the labour market, the allocation of welfare. Indeed many of our social and cultural practices have been premised upon and indeed reinforce the normality of the association between domesticity, child rearing and femininity. It is quite legitimate for men to be positioned within the public, as well as the private realm. Women must make a choice to remain in one or simply manage both and live with the real contradictions this poses. In the context of the reality of traditional social relations liberalism always:
.... constitutes a contradiction between women's intellectuality/ professionality and full expression of their reproductive sexuality. (Middleton, 1990, p. 71)

Such contradictions are exemplified graphically in the educational discourse of past policy documents. Until recently these were never uncovered in educational scholarship, because of the prevalence of certain social and intellectual features (O'Neill, 1992, pp. 69-70). ${ }^{14}$ Keynesianism helped sustain this intellectual milieu, which in turn produced theory which reinforced the hegemony of liberal ideology. When the ideology is unmasked to reveal its gendered assumptions then "equal" is certainly shown not to have meant the same for women as it did for men, as can be seen in the following policy documents.

\section{The Cohen Commission}

The evidence presented to the Cohen Commission (1912) mirrors the wider social struggles of the day and the basic educational struggle between those who wanted to retain the pre-meritocratic secondary system (and a classed social order), and those who desired the social fluidity a meritocracy would ensure. By the time it sat, educational opportunities for girls had opened up. They were engaging in new forms of physical exertion, certain parts of the labour market had become feminised, but the demands of certain "uppity" women for a greater "say" in the public realm, were thought to have usurped the natural fulfillment of feminine duty. Girls needed to be placed on their appropriate trackagain, in order to fulfil the demands of their "exclusive vocation". The complexity of the arguments of the time is apparent in what might have been seen as a radical view expressed by Headmaster, Robert Darroch:

The physical training of girls should be under the control of women, and in this connection I would advocate equal pay for equal work. Whilst I am uncompromisingly opposed to the higher education of our girls as destroying the beautiful lines and curves of their figures, robbing them of that charm and elusiveness that has so long characterised their sex, and, most important of all, weakening their powers of motherhood, yet I do think their primary education up to, say, the matriculation is even more important than that of our boys, because they are the future mothers of the nation, and that the head 
of a girls' school should be paid less than the head of a similar-sized boys' school is a neverlasting disgrace to our enlightened democracy. (1912, p. 674)

Many thought that girls should have access to education, but always contingent upon their future domesticity, and their central role in the upbringing of the nation's youth and strengthening the empire through their femininity and motherhood.

\section{The Thomas Report}

Published in 1944 this Report laid down the core curriculum, the basis of a general, liberal and "merit" based education, and it laid down a continuing prescription for the school to keep facilitating the production and reproduction of a gendered social order. It recommended that all girls were to receive instruction in home crafts as a part of the compulsory core:

We think that the course of every girl attending a postprimary school should contain studies and activities directly related to the home. We have provided for such studies in part through the optional subjects Homecraft and Clothing. In order to ensure that the needs are met of those girls who do not include these options in their courses we recommend that Home Crafts be included in the core. (Department of Education, 1942, p. 46)

The Report went so far as to prescribe the nature of the domestic activity women should be undertaking. It could include mothercraft, housewifery, house planning, dress design and pattern making, clothing, laundry work, cookery and meal planning (ibid, p. 46). In noting expansively what a parent might reasonably expect from this core for the child (always expressed as he) it said that he should be:

... able to listen intelligently to music, perhaps to sing or to play a musical instrument; and that he have acquired a reasonable degree of skill in an art or craft. An intelligent parent would wish a daughter to have, in addition, the knowledge, skill and taste required to manage a home well and make it a pleasant place to live in. (ibid, p. 17)
Thus men might fill up their leisure time in or outside the home pursuing the development of skills or active hobbies. Women's leisure time was quite clearly to be spent enhancing the home environment.

\section{The Currie Report}

The Currie Commission (1962) is widely understood to be the most comprehensive statement of post-war educational aims. It expressed ambivalence towards the value of post-primary education for young women. In noting the changing trend of female attainment of university entrance it said of girls:

More and more now go on to obtain their entrance qualification but there is no strong sign yet that they or perhaps their parents are convinced that it is desirable to continue this education to obtain a university qualification to the extent that this occurs with boys.

(Department of Education, 1962, p. 65)

While the Report noted this trend, it did not make any connections between it and its endorsement of the ideology of equality of opportunity. It signified that this trend should possibly be noted in future planning, but it did not advocate its sponsoring, or the importance for parents or teachers to do so. It said:

The motivations in this matter are likely to be complex and relate to the general attitude of the community, and of parents in particular, to the education of women, the extent to which women desire to enter professions or to combine them with marriage, and the earlier age for marriage that is beginning to prevail. A certain degree of change has clearly taken place. More may follow. (ibid, p. 66)

The Commission conceptualised the importance of further education for young women (whom it regarded as a pool of untapped talent) as useful to the country's future growth, rather than as a basic human right or as an essential measure in the redressing of wider gender inequalities. Thus it maintained that all they could do:

... is to draw attention to this marked increase in the pool of potential university degree talent in sixth form girls and suggest that this be not lost sight of in future planning. (ibid, p. 66) 


\section{The Johnson Report}

The publication of the Johnson Report (1977) was the subject of much controversial debate because of its "liberal" attitudes towards sexuality and human relationships. It was certainly not progressive in terms of gender relations. It acknowledged that discrimination towards women existed, but that public discussion should be about "the promotion of a wholesome interaction" between the genders rather than the rights of women (Department of Education, 1977, p. 83). It also noted the unsuitability of much of the liberation rhetoric of the time, saying it polarised, rather than brought, the "sexes ... into the closer, more harmonious relationship which is required" (ibid, p. 83). In an endorsement of traditional (essentialist) conceptions of masculinity and femininity, the Report argued that:

A girl must realise that it is possible to be a leader without losing an intrinsic femininity and boys must understand that they are not threatened with, or [need not] suffer from a loss of masculinity because a girl happens to have undertaken a leadership role. (ibid, p. 83)

It suggested that within the bounds of traditional masculinity, men could fulfil child rearing functions, but was careful not to question the content of masculinity or femininity or the sexual division of labour or the detachment or downgrading of women's association with domesticity. Indeed it openly acknowledged the necessity of unpaid work to the maintenance of contemporary society. The Report qualified the natural sanctity of home making and motherhood by arguing that it "should remain a dignified and honourable career preference" (ibid, p. 83). Equality was desirable, but this should not imply any change to the traditional patterns of gender interaction:

Notwithstanding our concern for equality of opportunity which would give women more choice to decide their own lifestyles, we believe that domesticity and the role of wife and mother will be the natural choice of many women and they should not be made to feel inadequate because of this. (ibid, p. 83)

The mediation of the outcomes or real effects of Government policy are complex, as the conclusion to this chapter argues. It is essential to acknowledge the basic citizenship gains that women have made under social democratic welfarism. It is also true that this policy basis helped ensure that women's day to day experience confirmed the separation of public and private realms. While welfare policies reached across from public to private they upheld a patriarchal structure of familial life, institutional organisation and social relations.

The election of the Fourth Labour Government in New Zealand in 1984 saw the beginning of a move to the right in economic and social policy on an unprecedented scale. The ideological struggles over this, during Labour's first term are well known (Jesson, 1989). After the 1987 re-election a more concerted attack on Keynesian welfarism ensured that the legitimacy of the previous education settlement was weakened (Grace, 1990, p. 170). ${ }^{15}$

Contemporary New Right ${ }^{16}$ liberalism is a restatement of the basic tenets of classical political and economic liberalism. The belief in competitive individualism, a reduced and controlled role for the state and the maximisation of the market are now known as libertarianism or neo-liberalism. Hence the basic ideas underlying these doctrines are not new; it is their contemporary interpretation which is. All versions can be said to embrace one central defining feature, based on:

... a qualitative shift in both policy and ideology against government intervention, which was condemned as collectivist, socialist and economically misguided. (Levitas, 1986, p. 3)

Coupled with this shift is a second political and economic tenet: the superiority of market mechanisms to ensure economic prosperity and the maximisation of individual freedom. Market forces should be allowed to operate as widely as possible within a social order that is understood to be capable of almost total self-regulation. There is no need for state intervention other than to minimise market distortions or offset market failures. Indeed within education such intervention has been blamed for the system's capture by its teachers, its massive inefficiency, its facilitation of middle class success and its failure to provide equality of educational opportunity (Treasury Briefing Papers, 1987).

There is now a substantial literature on the nature of the state's restructuring in terms of a neo-liberal agenda and its implications for educational provision (Munro, 1989; Codd et al., 1990; Lauder, 1990, 
1991; Lauder and Wylie, 1990; Middleton et al., 1990). Apart from Middleton's (1990) critique, there has been little discussion on the gendered assumptions of neo-liberal policy prescriptions as applied to educational relations. The differences between Keynesianism and neolibertarianism differ markedly, but within the bounds of the same problematic.

The model of life supposedly played out against the backdrop of the market is all pervasive in libertarianism. Every social transaction is conceptualised as entrepreneurial, to be carried our purely for personal gain. The "invisible hand" of the market is thought to be the most efficient way of sorting out which competing individuals get what (Bunkle and Lynch, 1992, p. 26). Even though it is thought to be an autonomous, apolitical and gender neutral mechanism, it is not independent of the values and customs of those who participate in it. As the Treasury Briefing Papers clearly showed, motherhood is an intervention between "rational" market transactions (as state education is an interposition between the customer/student and the provider/teacher). Thus, in Treasury's conception of the individual as the "rational man" (of the nineteenth century) Middleton argues that this now suggests having children implies a denial of:

... (patriarchal nuclear) families' greater income "and the material benefits that can provide." In other words, social and personal worth is measured by the acquisitive individual's production and consumption of wealth. Giving this up for dependency would therefore be irrational. The formal right of individual women to pursue both careers and motherhood is seen as justified, only on psychological grounds if it helps some (neurotic?) individual "be a more relaxed spouse and parent." (1990, p. 87)

Thus motherhood is openly acknowledged as a contradiction in market liberal discourse because it prevents effective competition. Childbearing and caring are reduced to the personalised concerns of the individuals involved, not structural matters to be accommodated by the state for the wider benefit of society. Likewise the benefits of increased education and occupational participation are seen to accrue only to an individual woman and her family (Treasury Briefing Papers, 1987, p. 57). This position is accompanied by Treasury's realisation of the value of unpaid domestic labour to the education of children as well as its reservations about childcare (Middleton, 1990, p. 87). This amounts to a traditional and contradictory endorsement of women either in the labour market (and childless and rational) or at home (where they should really be, but still irrational). The message here is confused; there is a juxtaposition between biologically essentialist understandings of femininity (and masculinity) in relation to child rearing and domesticity and the discourse of the rational non-gendered individual with no ethnic belonging pursuing his/her own ends in the neutral market place. The latter conception is of course a nonsense, but the reality of mediating both realms is now understood to be a personal aberration or oddity to be undertaken by only a few.

This discourse (as opposed to that of social democratic liberalism) overtly downgrades the role of childbearing, domesticity and unpaid labour through its overt association with irrationality. Yet it acknowledges the social value of such activities in the raising and educating of children, but completely ignores the economic value of this work. Non-commercial transactions cannot be accounted for. This model cannot acknowledge the realities of interdependence and dependence but relies on these features of social relations to sustain the public realm of the market. It assumes that:

... the processes of reproduction and of maintenance of human resources which are carried out unpaid by women, will continue regardless of the way in which resources are reallocated. (BarrattBrown, 1984, cited in Bunkle and Lynch, 1992, p. 27)

In one sense, women's association with the home is irrational, in another it is necessary and eternal. Unpaid domestic labour is thus regarded as elastic, able to stretch to make up any shortfall in other resources available for reproduction and the maintenance of human resources (ibid, p. 27). The welfare state sought to temper market outcomes through customary (monocultural and gendered) notions of justice, equality and fairness, and is now seen as a monstrous aberration in the lives of market-oriented individuals. The discourse and policy initiatives of Keynesian-welfarism were in some instances far more overt about the association between femaleness and motherhood. The discourses of neo-libertarianism still assume such links but they are either cast as a negative intervention in the market or tempered through the supposedly neutral language of "market-speak" with its emphasis on rationality and individuality. The very invoking of this so-called 
"rational" model (and the traditional form of familial organisation seen as necessary for functional social relations) implies the continued endorsement of patriarchal relations. It still embodies the contradictions between a woman's intellectuality and her reproductive sexuality and implies the legitimacy of the separate realms and the other dichotomies inherent in our social relations. Most centrally the "difference" or "difficulty" that femaleness or motherhood implies, is, against the pervasiveness of the market, interpreted negatively to mean "inefficiency" or "dependency". Thus this kind of economic model is based on:

... the learned male values of competition and aggressiveness and the adult male life cycle with an uninterrupted working life. As such it benefits only those who are able to take advantage of the market, and in New Zealand this means predominantly white, middle-class, able bodied men. (ibid, 27)

It is with an acknowledgment of these background assumptions that current policy initiatives must be understood (Lakatos, 1970; Olssen, 1987).

\section{The Draft National Curriculum}

The Draft National Curriculum was published in 1991 as a discussion document, and in the foreword to it, the Minister of Education tells us that it will enable the achievement of the success, knowledge and understanding and skills necessary for competition in the "modern international economy". This is so that we can "achieve the standards which, as a small trading nation, (we) need in order to prosper alongside other nations in the international marketplace" (Ministry of Education, 1991). Principle Five endorses the ideology of equal educational opportunities for all so that:

...schools must do all in their power to ensure that all students fulfil their potential and that barriers to achievement are removed. (ibid, p. 6)

Further, the Curriculum should:

... recognise, respect and respond to educational needs, experiences, achievements and perspectives of both female and male students, of all races and ethnic groups ... all programmes (should be) non-sexist, non-racist and nondiscriminatory. (ibid, p. 6)

This is a welcome recognition of the genderedness of school curricula. Unfortunately it is not backed by any concrete proposals as to how the above should be enacted. It is, of course, devolved to become the responsibility of the local community through the school. This must be remembered in relation to the changes to charter requirements that were signalled by the Minister in 1991. The focus on "social justice" was to be re-emphasised as "fairness to all" (to highlight the curriculum as opposed to equity requirements). The Minister maintained that "equity" should thus be optional rather than compulsory. By September 1992, there had been no changes made to the framework to the Charter requirements. At the end of 1992 it was expected that Treaty of Waitangi, equity goals and a gender inclusive curriculum would be shifted from the charters to the National Curriculum Framework (Monitoring Today's Schools, 1992, p. 2). (It is also worth remembering, in the context of the genderedness of school curricula, that the School Trustees' Association have no equity policy for girls.)

This National Curriculum discussion document designates the "Essential Learning Areas" of language, mathematics, science and environment, technology, social sciences, the arts, and physical and personal development. Four of the subject areas (English, science, mathematics, and technology) will be compulsory for all students to the end of Form Five. This Government has already announced the extension of the school leaving age to 16. The Drafts of two of these areas were published in 1992. In relation to gender inclusiveness they both give grand rhetorical signals.

The Science Draft Curriculum has two pages on girls and science and Maori and science. It acknowledges that many girls find science outside of their own experience and therefore do not pursue it to advanced career levels. In a most promising signal it suggests that:

Science education often undervalues the contribution of girls, provides unfamiliar contexts for their learning, and fails to develop their confidence in pursuing studies in this area. (Ministry of Education, 1992, p. 10)

This gives some acknowledgment to the vast research literature on gender and science which suggests that it is its very nature, its subject 
matter, its teaching and learning processes, rather than girls themselves, which have to change (Harding,1983; Burns, 1984; Bell, 1988). The Draft states that the concerns and experiences of girls are to be validated and that they are to be given positive role models in a context which is nonsexist and affords them as much time and attention as it does boys. These are all worthwhile educational aims, but again, nowhere are there any practical strategies for how to make them happen. There are "Possible Learning Experiences" accompanying each of the eight levels at which the achievement aims (the six topic areas) are to be taught. While they set out very interesting and wide ranging examples, both Pakeha and Maori, there do not appear to be many drawn from a domestic context.

The Draft Mathematics Curriculum, under the heading of Catering for Individual Needs acknowledges that in the past many students, particularly female and Maori, have "failed to reach their potential because they have not seen the applicability of mathematics to their lives" (Ministry of Education, 1992, p. 8). It, like the Science Draft, acknowledges the irrelevance and inappropriateness of the context in which mathematics was often taught. It points out that these two groups have"developed deeply entrenched negative attitudes towards mathematics as a result" (ibid, p. 8). It highlights the need for early success in mathematics, the low participation rates of female students at senior secondary level and the limiting effects of this on later career opportunities. The Draft states:

The learning programme pointers... include strategies that utilise the strengths and interests that girls bring mathematics (should be set)

in relevant social contexts, assigning cooperative learning tasks. (ibid, p. 8)

The Pointers (what students should be able to do) however, do not set out gender specific examples. In relation to the development of confidence, the Draft argues that girls "need to be encouraged to participate in mathematical activities involving ... estimation, construction and problems where there are any number of methods and where there is no obvious "right answer" "(ibid, p. 8). This is a recognition of the need to get girls to "have a go" in a non-threatening context. In one sense this is commendable, but dangerous of course if the same rigorousness in method and logic of argument is not required of girls as it is of boys.
Both of these Drafts follow the Draft Discussion Document in that they set out admirable rhetoric at the beginning but contain no concrete policy proposals, teaching strategies or gender evaluation mechanisms. Indeed, the Ministry have praised themselves for the inclusion of these statements (Report on Policy Project Phase One, 1992, p. 4). Given the problems that we know are associated with getting some male teachers (who predominate in both maths and science teaching) to take gender inclusiveness and learning contexts for girls seriously in any way, this is most problematic. Given that sociological analyses of education have demonstrated the salience of the hidden curriculum and the reality of class, ethnicity and gender as structural barriers in every classroom interaction, this is hardly good enough (see the contributions in Codd, Harker and Nash, 1992). Warm and fuzzy rhetoric at the beginning of policy documents without real strategies, real guidance procedures and real monitoring processes amounts to a continued non-recognition of the subjective and structural reality of gender.

The numbers of females taking maths and sciences remains just under that of males, at secondary school level. Women constituted $7 \%$ of Engineering, 34\% of Technology and 36\% of Science students in all internal university courses in 1987 . They made up $7.26 \%$ and $26.7 \%$ of full and part-time $\mathrm{PhD}$ enrolments in those respective areas in the same year (O'Neill, 1992, pp. 62-63). There are many science departments in universities and research institutions up and down the country with none or one or two women in them. Real recognition of the rhetoric in the form of changes in practices of girls, parents, teachers and institutions is what is needed to redress this imbalance, not more rhetoric.

The New Zealand Educational Institute (NZEI) (1991) response to the Draft Curriculum suggested that assessment targets and objectives needed to be broad enough to allow schools flexibility to plan their own programmes, while being specific enough to enable teachers to decide on individual student needs. Flexibility in catering for individual students, particularly in empowering and encouraging girls is important. While resistance to the technicism and functionalism underlying current educational restructuring is imperative, it would seem that such tendencies might well be used to implement the kinds of strategies that could bring about real change in outcomes for girls and women. 


\section{The National Certificate}

The National Certificate is a comprehensive academic and vocational certificate which will subsume a number of earlier qualifications in postcompulsory education and training. It fits into the National Qualifications Framework and covers Levels 1-4. It is composed of discrete units/standards available at every level. Qualifications will be made up of tailored packages of units which are linked and interchangeable. There will be cross-crediting of units between qualifications and also between places of learning. It will encourage learning in vocationally related topics to be studied in senior secondary school, polytechnics, business firms, or with other private providers. All of these groups are contributing to the content of the units.

Hundreds (of what will be thousands) of these units will be available in certain pilot schools in 1993. The Minister of Education sees this as a profitable strategy because it "will lead to a more successful New Zealand, economically" (NZQA, 1992, p. 4). The introductory booklet acknowledges the present realities of labour market restructuring when it says the average worker may well have to change direction many times in a working life. Perhaps these units may help people keep abreast of this. The "recognition of prior learning" that this certificate will accommodate is one of the most cheering signposts on the "rightist" 1993 horizon. Women have many skills, attributes and capabilities that they bring to the paid workforce. This certificate could provide an official mechanism for their formal recognition within a national qualification. It remains to be seen how this will work in reality and what implications it will have for the continued ideological designation (and differentiated remuneration) of occupations within the labour market as specifically male or female.

\section{Parents as First Teachers}

The Parents as First Teachers programme is based on a Missouri parent education research project, commissioned by their State Department of Education in the early 1980s. It has a strong health-education focus so that both disciplines will be drawn upon to support parents in the parenting role, from birth until three years. The Ministry maintains that such a programme is compatible with our "early childhood philosophy of high parent involvement in education programmes for young children and will fit in well with the present range of support services available to families with young children" (Ministry Handout, undated). However as Hamilton and Bird point out:

... the research of the Missouri group ran counter to the Zeitgeist of research in early childhood at the time, which tended to focus more on the quality of interaction between caregivers (both parents and professionals) in early childhood settings, rather than upon at-home intervention designs (which had been more popular in the 1970s). In the United States, research has moved away from the "Head Start" era of intervention in parent training, with its lack of attention to possible cultural insensitivity of "expert" researchers working with families of non-dominant ethnic groups. (1992, p. 67)

This programme, coordinated by the Plunket Society, was, at the end of 1992, at the stage where parent educators were enrolling families in four pilot areas; Northland, South Auckland, Gisborne-East Coast, and Dunedin. There are 125 parents in each area. Eight parent educators with early childhood experience undertook a one week training programme and will work with these parents. On the face of it, this looks like an interesting policy development. The Minister of Education in 1991 made it quite clear that the poor educational achievement of certain groups (working class and Maori families?) could be enhanced through more skilled parenting. Given the location of the pilot schemes, one presumes the programme is targeted at such groups. It remains to be seen how cultural difference will be negotiated and accommodated in the evaluation process. Looked at in the overall policy context pursued by this Government, perhaps the scheme is an attempt to compensate those groups who have borne the brunt of its economic policies, and the retraction of vital state services so essential to their ability to parent. Or perhaps this should be read as yet another attack on poor, Maori and Polynesian women, who are the supposed causes of the educational and vocational failure of their children? Given what we know about the way class-located families reproduce themselves and the complexity of gender and ethnicity in this reproduction, this is an area in which the application of simplistic strategies could certainly do more harm than good. (See Codd, Harker and Nash, 1992) 


\section{Study Right Policy}

The National Government's Study Right policy introduced in 1992 replaced Labour's standard tertiary fee of $\$ 1,300$. Driven by the desire to reduce the fiscal deficit and keep to its manifesto commitments, the Government established a funding regime which ensures the state subsidises course costs up to a certain level, while tertiary institutions are free to set their own fees. There are two categories of qualifying students: school leavers up to the age of 22 years and some beneficiaries, the long term unemployed and those on the Domestic Purposes Benefit. A school leaver must have enrolled in a tertiary institution by the set age or else forego access to the grant permanently. After establishing entitlement it is available up to and for the whole of the year in which the student is 24 on 1 January. If not used by the 25 th birthday the only way it can be, is if a person does so as a beneficiary. Student allowances for 16-24 year olds are now means-tested against parental income and a state funded income based loans scheme has been established to provide assistance for students.

Domestic students undertaking wholly research-based postgraduate courses will be able to compete for special supplementary grants covering $95 \%$ of their tuition costs. Those undertaking courses comprising papers only or papers and research will be subsidised by $85 \%$ in 1992, falling to $75 \%$ by 1994 .

Under Study Right in 1993 the state will pay $95 \%$ of the $\$ 25,355$ fee for one year of a medicine degree. This amounts to $\$ 24,088$, leaving a fee of $\$ 1,267$. Under non-study right it will pay $80 \%$ (it will be $75 \%$ in 1994), which is $\$ 20,285$, leaving a fee of $\$ 5,070.80$. This is a substantial amount given the length of time it takes to gain such a degree. It is also important to remember that the fee level is determined by the individual institution. Some do not differentiate between courses, others pass on higher fees than those demanded by the Government.

Even though these changes are relatively new, they have huge implications for women. While it is a blessing that the entitlement is still available to beneficiaries, Study Right gives a very clear message to people over 22 years who are not on a benefit. The state is effectively saying to them that it does not want to assist them to educate themselves, it sees no value or worth in it. For a government so obsessed with telling us we are unskilled, lazy and unproductive as a nation this is strange. Certainly non qualifiers can go to university - but they will have to pay more.
As Boston (1992, p. 191) has pointed out, the favouring of school leavers at the expense of mature students (of whom $66 \%$ of those over 25 years were women in 1990) is "discriminatory, inequitable and inefficient and represents one of the most unsatisfactory aspects of the new policy framework". These policies will have major long-term implications for the staffing of universities and the level of advanced research being done in this country. Many undergraduate degree programmes are four years (law, medicine, engineering) or more in length, so restricting Study Right to three years discriminates against those wishing to take such courses. It discourages people from taking joint degrees and provides an incentive for universities to reduce the length of certain programmes to maintain demand. It will also contribute to the reduction of the number of New Zealanders with appropriate qualifications for holding research or academic positions in the country. There are so few women in such positions. In 1987 there were 14 women professors in our universities and in 1991 the number was the same (Education Statistics, 1988, 1992). This disastrous state of affairs will remain unchallenged unless significant numbers of women continue through to graduate studies. Women are structurally disadvantaged in relation to men in terms of their earning capacity, ${ }^{17}$ their domestic commitments, their attainment of advanced qualifications and in their access to employment where further study might be sponsored by an employer. Hence the numbers of women who access "second chance" education to advance themselves is high and thus the present policy is particularly devastating for women, and their future access to corporate, professional and research based careers. ${ }^{18}$

The loans scheme mediates some of the worst features of these changes and the fact that many institutions have refused to implement Study Right as intended is heartening, but as Boston (ibid, p. 205) points out, it is questionable whether the responsibility for ensuring equitable access to tertiary education and training should rest with the councils of tertiary institutions. Historically they have had very little to say or do about the structural divides they help to create and maintain in our society.

The Disestablishment of the Girls' and Women's Section, Ministry of Education

In 1991 the Government disbanded the Women's Advisory Committee on Education (WACE). This eleven woman committee was concerned 
with the formation of a national policy for the education of girls and women. It reported directly to the Minister of Education and was an important lobbying group for the establishment, under Labour, of the Girls' and Women's Section in the Policy Division of the Ministry of Education. 1991 saw the demise of WACE; 1992 saw the demise of this section in the Ministry. This four-person unit had been set up in 1989, and like many affirmative action initiatives its existence and effectiveness had always been under scrutiny. The demise of the Committee was announced as part of a larger programme of Ministry restructuring of its policy division (in which fifteen positions would be cut) in September 1992. It is proposed that four of six new policy units will include an analyst with a focus on educational outcomes for girls and women. This will mean that in line with the rest of the state sector, the Ministry will spend more money to get outside specialist advice on contract. The Ministry Head, Dr O'Rourke, claimed that such changes would "improve management by creating shorter control lines and closer access to senior management" (Evening Post, 23 October, 1992).

The axing of this unit, like much of the other restructuring in the state sector, drew public criticism. Helen Pearce (Watson), who has experience of working closely with the Department and the Ministry, pointed out, in a response from the Post Primary Teachers' Association, that the scattering of gender responsibility throughout the Ministry prior to 1986 had not worked well. She stated:

New Zealand has been extremely poor in addressing the concerns and needs of women and girls in education since these were raised as an issue in the 1970s. The commitment by ministers of education, the former Department and the Ministry have been grudging and inadequate at best and non-existent at the worst. In comparison to Australia, Canada and Britain, New Zealand has done very little in this area (September, 1992).

The Girls' and Women's Policy Unit was to be involved in contributing to twenty projects over the 1991-1993 period. The axing of this unit speaks volumes about the present Government's commitment to eliminating educational disparities between men and women and groups of women. They have no such commitment.

\section{Report on Policy Project Phase One, Girls and Women Section, Policy} Division, 13 December 1992

The Dominion newspaper chose to greet its readers on the first day of 1993, the year of the anniversary of women's suffrage, with the front page headline "Education 'failing' females". In what is becoming an increasingly common practice in the current policy climate, the Report in which this was documented was obtained under the Official Information Act. It provides an extremely candid statement on the overall lack of progress that women have made in education. This is particularly interesting in the light of the Ministry of Education's perceived lack of need for the Girls' and Women's Policy Section. It is obvious why the Ministry needed to keep this information from the public as it was axing the Section. However there is nothing in the Report that those working in the area, including many teachers, did not already know. The Report says that girls and women are still not achieving their full potential in terms of post compulsory education and occupational choices. Despite higher retention rates, they are still being steered into traditionally female career choices that provide the opportunities for long term employment and advancement.

This Report claims the draft curriculum may help rectify this because of the provision of experiences that "enable girls to utilise their strengths and interests" (1992, p. 4)! Some of the most important comments in it pertain to Maori females whom it acknowledges are particularly disadvantaged and "warrant specific consideration". Maori students (male and female) make up $21 \%$ of the total primary population and $15 \%$ of the total secondary. In 1977, $28 \%$ of Maori females left school without qualifications and in 1987, 33\%. In 1990 the figure was $34.8 \%$ compared to $14.8 \%$ of all girls. This figure has always been high, but it is now even more disturbing because of changes in assessment procedures (see O'Neill, 1990, p. 79). Now, any one subject studied for School Certificate is awarded a formal grade, rather than an overall pass or fail mark. The change in grading procedures should have meant this figure declined but it has continued to rise. Of the effects of low participation and low retention the Ministry states that this:

... causes lifelong disadvantage. Maori females have low levels of formal qualifications, often leading to low pay, unemployment and high benefit dependency. (1992, p. 3) 
What needs to be remembered is that these figures represent predominantly working class Maori girls, not those from well resourced middle class families. What I am at a loss to understand, is why as a society we do not perceive this to be the national scandal that it is? Why are Maori so silent about these figures? Why are they not discussed fully in mainstream sociological accounts of either praxis or policy? Why do they not feature as a subject for discussion in university courses? Why do many colleges of education not even acknowledge the salience of gender as a structuring mechanism, let alone the specifics of its effects when combined with ethnicity? Why are resources not directed to the analysis of this and most centrally to its redressing? Why is this Government so silent about these figures, given its persistent rhetoric about the relation of lack of skills to unemployment, economic inefficiency and our lack of international competitiveness? Perhaps the last word should go to the Ministry, in what must be a damning indictment of its own position and the axing of the Girls' and Women's Section:

... there have been few major advances. Policy on its own is unlikely to change educational outcomes for girls. In order to achieve the Government's educational outcomes policy decisions need to be backed up by a framework for action. (ibid, p. 2)

\section{Conclusion}

This chapter has outlined some of the major policy initiatives which will impact upon the educational trajectories of all female students. In the short space of writing this, many features of the current education settlement have been discussed in the press. For example, the nonqualification rates of Maori females have been made public (this has provoked no comment at all); the Education Review Office, which reviews equity requirements in schools, is to lose thirty five staff; a report released by the New Zealand University Students' Association has confirmed the privileged backgrounds of university students.

The current administration claims to be pursuing a policy of equality of opportunity in relation to education. Yet it is clear that there are still areas of provision that certain groups of women are not accessing. This has been the case since it was brought to public attention by feminist sociologists at the beginning of the 1970s. Many young Maori women are leaving school without basic qualifications, which directly impacts upon their future quality of life. There are still certain areas of the sciences and technologies in which women are almost not present at all, either as researchers or students. Although it is difficult to prove statistically, anyone who teaches in a university knows that working class women are a rarity there.

It is commonplace for people to respond to these kinds of claims by reiterating that, for example, females now constitute over half the medical and legal graduates in this country. This may be so, but it is important to remember that these are the daughters of middle class families (who, in smaller numbers have always accessed higher education) whose reproductive strategies now encourage them, as well as their sons into the professions. As in every other employment area, women in these professions are concentrated in certain feminised sectors which do not provide the status or influence or remuneration that the more "public" male areas do. Women are not attaining specialist medical positions or legal partnerships in the way their numbers indicate they should.

The Labour Government's "great design for education" (Grace, 1990) embraced the rhetoric of equity, which in David Lange's eyes went hand in hand with "efficiency" and "standards". When placed in the overall context of diminishing state resources, the devolution of decision making to community level (which is inherently gendered, racist and classist) plus the reassertion of a rarefied notion of the individual, any emphasis on structural disadvantage or achievement outcomes for certain sectors is considerably diminished, both at the level of ideology and praxis. It is now up to the individual (or community consumers) freely to pursue (or consume) her/his own equal opportunities. The provision of greater choice, rather than any evening out of structural disadvantage, is the role the state sees it has in this. Certainly this administration's policy initiatives, or lack of them, in relation to gender differences in education (which they do not see are linked to differences in life chances or ability to even participate, let alone compete in the market) verify this.

Thus it is questionable as to whether equality of educational opportunity exists for certain groups of women in this country. Under Keynesian inspired policies the essential nature of women was seen in relation to domestic labour, child bearing and rearing, frequently overlaid by the rhetoric of equality of opportunity. More often than not, this association was "positively" or overtly emphasised, even though its 
value was never economically calculated. The market model of social life sees this unpaid labour as out of the sphere of "rational man" so it is therefore irrational. Yet in its convoluted way the market model acknowledges that the private sphere is essential to the survival of the public. Still, the economic value of this labour remains uncalculated and hence hidden (but now irrational).

While the hegemony of the market model cannot be doubted at the present juncture, its centrality cannot be captured through functional understandings of the state. Its workings are better understood through a realisation of its nature not as a rigid

... manifestation of a patriarchal essence, but ... the centre of a reverberating set of power relations and political processes in which patriarchy is both constructed and contested. (Connell, 1987, p. 130)

The state is specifically a site of socio-political struggle, the complex institutionalisation of power relations which work in cohort with other mechanisms in civil society, for example the institution of heterosexuality, the family or the education system. It is continually seeking to generate consent among many groups, dominant and subordinate, and this means that it engages in internally and externally contradictory activities in order to do so (Saville-Smith, 1987). Thus the state has an ambiguous nature. It must ensure favourable economic conditions but it can both facilitate as well as endanger the reproduction of the dominant patterns of class, gender and ethnic relations. New Zealand's present administration is facing serious legitimacy problems as the imperative which lies behind so much of its restructuring policy, the reduction of the fiscal deficit and the furthering of the interests of elite groups whom it sees as beneficial to the accumulation process, remains crystal clear. There are few who now believe the state explanations for policy changes that are given, have any locus other than economic. The generation of consent is contested and fought over at all sites. Thus the mediation of the policy initiatives this chapter has discussed will not happen in any mechanistic or linear way, either at Ministry level, in educational institutions or in the lives of women students. Women will struggle on and overcome traditional patterns, structural barriers and economic hurdles to gain access to advanced qualifications, in the same way that they have always done. However they will be those women who already have the resources to do so, be they financial, social or emotional. They will be from those groups in society better positioned to withstand the onslaught of the other economically inspired policy changes that have impacted upon them. Given the way families reproduce themselves and coupled with the open disdain that this administration's policy initiatives have shown for the poor, I feel less positive about the educational trajectories or the life chances of girls and women in this group than ever before. Many of these families already exist within a poverty cycle and the "free market" is about exacerbating these inequalities not diminishing them, hence it is about the continuation of the "feminisation of poverty". Likewise, educational policies have never really been concerned with the life chances of this group, and, as this discussion has shown, they are even less so now.

Notes

1. At that time the justification of this "knowledge area" in the universities was still necessary, and this meant the need to get staffing and resources, the building up of a literature and the need to have genders included in mainstream sociological and educational accounts.

I would like to thank Helen Leahy from the Ministry of Education for her help in collating information, other staff at the Ministry for sending me the appropriate policy documents, Bronwyn Cross from the PPTA and Cathie Bell from The Dominion.

2. The previous settlement originated in the principles underlying the establishment of the welfare state in the 1930s. Education was at the centre of the social, political and economic transformation to be undertaken.

3. Male defined, centered and dominated.

4. These are the official September 1992, seasonally adjusted figures. "Employed" means anyone working over one hour per week including those doing one hour or more unpaid work in a family business and those working on the Community Taskforce. "Unemployed" means those available and actively seeking work, or waiting to start a new job in one to four weeks. Anyone who does not fit into these categories (including all students and people on training schemes) is excluded from the survey. The unemployment rate for males was $11.1 \%$, for females $9.2 \%$. The rate for Maori was 27.1\% in June 1991 (Dalziel, 1992, p. 211). The extension of the category of "employed" skews these figures. Certain people on six month stand-downs are not included and the official figures have never taken into account hidden unemployment, those in other benefit categories and traditional female unemployment or under-employment. 
5. This term refers to the overall organisation of the production process. It is the balance that must be maintained between the conditions necessary for the operation of production and those necessary for the consumption of products. This implies the reproduction of a whole social and economic schema. Such a regime is constituted by both a mode of accumulation and a mode of regulation. The former is the nature of the organisation of the production process, the latter the nature of the broader social environment of production.

6. The enactment of policies underlaid by Keynesianism resulted in the modification of the basic foundations of capitalism. The growth in state intervention ensured that internal governments became responsible for the general economic condition of their economies. The regulation of internal industries, through monitoring agencies or most often through direct public ownership, occurred in most western democracies.

7. Wilkes (1989) points out that monetarism began to dominate our economic officialdom from 1975 onwards. As Barry (1987) and Gamble (1986) have argued, the resurgence in state interventionism had never completely defeated the doctrines of laissez-faire economics (or indeed neo-liberal world views).

8. In this country neo-libertarian economic and social ideas have been accompanied by the those of the neo-conservative authoritarian right, who invoke essentialist (biologically based) conceptions of gender and gender relations.

9. Neo-liberals acknowledge one central right, and that is to own private property.

10. The sexual division of labour refers to the allocation of work on the basis of gender, within the home and the workplace. It also refers to that division between the home and the workplace which has been characteristic of capitalism. The division of labour operates through a series of dichotomies (which have been mentioned in the body of this article) which refer to male and female spheres and also correspond to the social divisions that are characteristic of capitalism (e.g., production/ consumption, public/private, work/non-work).

11. Keynesian principles were consistent with those of a Fordist regime of accumulation and mass production, the main features of this mode of regulation being an interventionist state, collective wage negotiation, the relation of wage to productivity levels, the imposition of pricing control mechanisms and an uncontrolled money supply.
12. Historically under capitalism, many state initiatives have had the effect of constraining certain groups of women to certain limited choices in their lives. Traditionally these have reinforced the dominant (class and ethnically based) patterns of male entry and participation in the public world of work and the female relegation to the private sphere of domesticity and the home. Such enabling or constraining influences can be identified through the state's direct or indirect intervention into such mechanisms as the labour market, the provision of a gender differentiated curriculum, its overt or covert encouragement of heterosexual marriage, the nature of its welfare benefits, its commitment to equal pay for work of equal value within a feminised labour market, its sponsorship of childcare or the availability of educational access or grants throughout the life cycle. Thus the historical and contemporary influence of such constraining factors on the lives of women should not be forgotten in an analysis of the state under capitalism.

13. Saville-Smith's (1987, p. 210) analysis of the Domestic Purposes Benefit in New Zealand demonstrates the contradictions inherent in the state's position. This benefit signifies and encourages women's dependency and the legitimacy of marriage. It also provides an escape from marriage while undertaking full-time childcare. While it is a transfer from one set of dependency relations to another, it constitutes a threat to patriarchal power at one site. The payment of this entitlement to women constitutes a myriad of contradictions the state must mediate. James and SavilleSmith (1989) also discuss this contradictory nature historically, in relation to the emergence of state welfare legislation. They argue that the 1894 Married Women's Property Act worked as a reinforcer for the "Cult of Domesticity" so as to usurp the threat to social relations that wifedesertion posed, but it also gave women basic civil-rights and a chance to leave unsatisfactory marriages.

14. Most notably the myth of equality of educational opportunity has been an integral part of what historians have termed the liberal ideology of egalitarianism so pivotal to our growth and development as a nation (McKenzie, 1980). Such myths and the liberal rhetoric of educational discourse, should be understood and analysed as having the effects of a material force within education. Like other dominant ideologies that shroud the real nature of social relations (and all the contradictions we must personally mediate) they have worked to mask and hide from critical enquiry deep-seated contradictions within the system (Codd, Harker and Nash, 1985, p.10). This was evident in the omission of gender considerations from mainstream educational research. 
15. The political and social milieu and the continuing fiscal crisis of Keynesian welfarism and the erosion of the consensus between labour and capital paved the way for changes to the mode of accumulation.

16. “This has been exacerbated by the fact that the system's myths (had been) exploded and rationale undermined by powerful left-wing criticisms, (which had made it) ... all the more vulnerable to attack from the Right." (McCulloch, 1990, p. 61)

17. The meaning of this term is contentious both among its proponents and its critics. It constitutes an amalgam of various social, economic and political doctrines which can be grouped under its broad rubric.

18. For Althusser (1970) the problematic referred to the central issues of the basic metaphysical and ontological commitments, the kind of relations between basic entities, what constitutes an explanation, what general laws hold, the specifics of method and methodology.

19. An examination and understanding of girls' educational experience necessitates the analysis of an entire set of micro-environmental influences which are implicitly and explicitly exerted upon female pupils. These include the gender relations underpinning their familial setting, the girls' projections of their futures, perceptions of parental aspirations and the actual social and material resources available for them to make use of within particular contexts. They also entail the structural constraints that impinge upon girls in their transition through school and into the labour market, e.g., school subjects available, school selection mechanisms, occupational recruitment policies, employer attitudes, job availability, and legislative guidelines. Labour market demands in a time of economic restructuring are also of paramount significance.

20. In November 1987 the average hourly earnings of men in all sectors of employment were $\$ 12.60$, and the average weekly earnings $\$ 470.80$. For women they were $\$ 10.25$ and $\$ 364.46$ respectively. In November 1988 the rates had risen so that the average hourly earnings for men were $\$ 13.73$, with average weekly earnings of $\$ 512.00$. Women still trailed behind with an average hourly rate of pay of $\$ 11.17$ and average weekly earnings of $\$ 397.00$ (see O'Neill,1990 for further discussion).

21. During the decade 1977 to 1987 the number of women enrolled as internal (full and part-time) university students increased from $39.5 \%$ to $48 \%$. By 1977 the proportion of women full-time internal students was $35 \%$ and in 1987 this had risen to $43 \%$ (as opposed to men who were $56.5 \%$ ). In 1987 women comprised $61 \%$ (as opposed to $39 \%$ of men) of extramural students at Massey University. The total internal and extramural student population was 11,419 women and 8,703 men (Department of Education, 1988, pp. 153-154, cited in O'Neill,1990, p. 80).

22. In $1981,50 \%$ of families with incomes of less than $\$ 8,000$ a year were solo mother households. Solo parent households made up only $6.2 \%$ of all household types that year (Saville-Smith, 1987). By 1986, solo mothers headed one in three Maori families. It is now nearer one in two. The characteristics of this group are: $76 \%$ with no school qualifications, compared to $66 \%$ of the total Maori population. $78 \%$ were on a benefit. They were more likely than their Pakeha counterparts never to have been married, to be young, unemployed and impoverished. Older Maori women on their own were more likely to be heading large families of four or more children (Metro, November, 1992, p. 95).

\section{References}

Althusser, L. and Balibur, E. Reading Capital. London: New Left Books, 1970.

Arnot, M. "Sociocultural Reproduction and Women's Education" in Deem, R. (ed) Schooling For Women's Work. London: Open University, 1980.

Barry, N. The New Right. London: Croom Helm, 1987.

Bell, B. "Girls and Science" in Middleton, S. (ed) Women and Education in Aotearoa. Wellington: Allen and Unwin, 1988.

Boston, J. "The Funding of Tertiary Education: Rights and Wrongs" in Boston, J. and Dalziel, P. (eds) The Decent Society? Auckland: Oxford University Press, 1992.

Bunkle, P. and Lynch, J. "What's Wrong With the New Right" in Briar, C. et al. (eds) Superwoman Where are You? Palmerston North: Dunmore Press, 1992.

Burns, J. "Girls in Science" in Towards the Year 2000. Proceedings of The Fourth Biennial Conference of New Zealand Science Teachers Association, 1984.

Burton, C. Subordination: Feminism and Social Theory. Australia: George and Allen Unwin, 1985.

Codd, J. A., Harker, R. K. and Nash, R. (eds) Political Issues in New Zealand Education, First edition. Palmerston North: Dunmore Press, 1985.

Codd, J. A., Harker, R. K. and Nash, R. (eds) Political Issues in New Zealand Education, Second Edition. Palmerston North: Dunmore Press, 1990.

Codd, J. et al. "Introduction: Education, Politics and the Economic Crisis" in Codd, J. et al. Political Issues in New Zealand Education, Second Edition. Palmerston North: Dunmore Press, 1990.

Connell, R. W. Gender and Power. Cambridge: Polity Press, 1987.

Cox, S. and James, B. Introduction in Cox, S. Public and Private Worlds. Wellington: Allen and Unwin, 1987. 
Dalziel, P. "Policies for a Decent Society" in Boston, J. \& Dalziel, P. (eds) The Decent Society? Essays in response to National's Economic and Social Policies. Auckland: Oxford University Press, 1992.

Department of Education, Education Statistics of New Zealand. Wellington: Department of Education, 1988.

Department of Statistics, New Zealand, Household Labour Force Survey, September 1992 Quarter.

Evening Post, 23 October, 1992.

Gamble, A. "The Political Economy of Freedom", in Levitas, R. (ed) The Ideology of the New Right. London: Polity Press, 1986.

Grace, G. "Labour and Education: The Crisis and Settlements of Education Policy" in Holland, M. and Boston, J. (eds) The Fourth Labour Government Politics and Policy in New Zealand. Second Edition. Auckland: Oxford University Press, 1990.

Hamilton, C. and Bird, L. "Impact of 1991 Policy Initiatives for Girls and Women in Education: Fibre and Fishhooks" in Manson, H. (ed) New Zealand Annual Review of Education, 1:1991. Wellington: Victoria University of Wellington, 1992.

Helly, D. and Reverby, S. (eds) Gendered Domains: Rethinking Public and Private in Women's History. New York: Cornell University Press, 1992.

Hill, L. "The Budget Blues or: How Economics Makes Women Disappear", Broadsheet. Spring, 1992.

James, B. and Saville-Smith, K. Gender, Culture and Power. Auckland: Oxford University Press, 1989.

Jesson, B. Fragments of Labour: The Story Behind the Labour Government. Auckland: Penguin, 1989.

Lakatos, I. "Falsification and the Methodology of Scientific Research Programmes" in Lakatos, I. and Musgrove, A. (eds) Criticism and the Growth of Knowledge. Cambridge: Cambridge University Press, 1970.

Lauder, H. "Education, Democracy and the Crisis of the Welfare State" in Lauder, H. and Wylie, C. (eds). Towards Successful Schooling. London: The Falmer Press, 1990.

Lauder, H. "The New Right Revolution and Education in New Zealand" in Middleton, S. et al. (eds) New Zealand Education Policy Today. Wellington: Allen and Unwin, 1990.

Lauder, H. and Wylie, C. (eds) Towards Successful Schooling. London: Falmer Press, 1990.

Lauder, H. The Lauder Report, P.P.T.A., 1990

Levitas, R. The Ideology of the New Right. Cambridge: Polity Press, 1986.
McCulloch, G. "The Ideology of Educational Reform: An Historical Perspective" in Middleton, S. et al., New Zealand Education Policy Today. Wellington: Allen and Unwin, 1990.

McKenzie, D. "The History of New Zealand Education", Research in Education in New Zealand: The State of the Art, NZARE/Delta Research Monograph 3, 1980.

Middleton, S. "Women, Equality and Equity in Liberal Educational Policies 1945-1988" in Middleton, S., et al. (eds) New Zealand Education Policy Today. Wellington: Allen and Unwin, 1990.

Middleton, S. (ed) Women and Education in Aotearoa. Wellington: Allen and Unwin, 1988.

Middleton, S., et al. (eds) New Zealand Education Policy Today. Allen and Unwin, Wellington, 1990.

Ministry of Education Mathematics in the National Curriculum. Draft, 1992.

Ministry of Education Monitoring Today's Schools, Report No. 14. Charters and Policies. 1992.

Ministry of Education Report on Policy Project Phase One. Girls and Women's Section, Policy Division, 1992.

Ministry of Education Science in the National Curriculum. Draft, 1992.

Ministry of Education Education Statistics of New Zealand. Wellington: Ministry of Education, 1992.

Munro, R. The Munro Report, P.P.T.A., 1989.

New Zealand Qualifications Authority Learning to Learn. 1992.

New Zealand Treasury Government Management, Volume II: Education. Wellington, 1987.

NZEI. NZEI Response to the National Curriculum Discussion Document. Wellington: NZEI, 1991.

O'Connor, J. Accumulation Crisis. Oxford: Basil Blackwell, 1984.

O'Connor, J. The Fiscal Crisis of the State. New York: St Martins Press, 1973.

O'Neill, A. M. "Gender and Education: Structural Inequality for Women" in Codd, J. A., Harker, R. K. and Nash, R. (eds) Political Issues in New Zealand Education, Second Edition. Palmerston North: Dunmore Press, 1980.

O'Neill, A. M. "The Gendered Curriculum: Home-Makers and Breadwinners" in McCulloch, G. (ed) The School Curriculum in New Zealand. Palmerston North: Dunmore Press, 1992

O'Neill, A. M. "The Equal Opportunity Myth: Women in New Zealand Educational Institutions", in Olsson, S. (ed) The Gender Factor: Women in New Zealand Organisations. Palmerston North: Dunmore Press, 1992.

Olssen, M. "What Really Happened? Varieties of Educational History" in Openshaw, R. and McKenzie, D. (eds) Reinterpreting the Educational Past. Wellington: NZCER, 1987. 
Pateman, C. The Disorder of Women. California: Stanford University Press, 1989.

Report of the People's Select Committee, (1992) Neither Freedom nor Choice. Palmerston North: Massey University, 1989.

Saville-Smith, K, "Women and the State" in Cox, S. (ed) Public and Private Worlds. Wellington: Allen and Unwin, 1987.

Sharpe, R. Knowledge Ideology and the Politics of Schooling: Towards A Marxist Analysis of Education. London: Routledge and Kegan Paul, 1980.

Smith, Hon. Lockwood, Education Policy: Investing in People, Our Greatest Asset. Wellington: Government Printer, 1991.

The Dominion, 1 January, 1993.

Theoborn, G. The Ideology of Power and the Power of Ideology. Great Britain: Verso, 1980.

Wilkes, C. "The Art of the State" in NZPSA Private Power or Public Interest? Widening the Debate on Privatisation. Palmerston North: Dunmore Press, 1989.

\section{The author}

Anne-Marie O'Neill is a Lecturer in the Education Department at Massey

University where she has taught, inter alia, the Sociology of Women's

Education, the Sociology of Education, curriculum theory and educational policy analysis. 